\title{
Chinese-to-English Translation of Publicity on Chinese Minority Culture From Narrative Perspectives
}

\author{
XIAO Tang-jin \\ Guizhou Minzu University, Guiyang, China
}

\begin{abstract}
Narrative is a literary notion. In narrative translation theory, narrative involves personal narrative, public narrative, disciplinary narrative, and meta-narrative. This paper adopts the notions of personal narrative, public narrative, and meta-narrative to analyze specific cases concerning the Chinese-to-English translation on Chinese minority culture publicity, proposes two narrative translation models, namely, the annotation narrative translation model and the manipulative narrative translation model, and explores the concrete translation procedures and the embodied meta-narrative, covering introduction to minority tales, minority festivals, and minority customs. Narrative translation research is part of the multidisciplinary or interdisciplinary turn in the 21st century, and this research is an organic part of cross-cultural communication translatology.
\end{abstract}

Keywords: narrative, Chinese-to-English translation, publicity on Chinese minority culture, model

\section{Foreword}

Cross-cultural communication translatology explores translation theories and practice from the perspectives of cross-cultural communication based on multiple disciplines. Thus, it shows interdisciplinary, intercultural and interlingual features (Xiao, 2018). This means that it is different from conventional approaches to translation in theory and practice, such as form equivalence and functional equivalence. Nowadays, narrative, an approach in literary studies, and sociology, a discipline which studies social structure, social mobility, and other social issues, are also adopted in translation studies. They are labeled as "interdisciplinary turn", "sociological turn", "power turn”, and other things alike. In this essay we shall examine the concept of narrative in literature and translation respectively, propose two models for narrative approach to translation, and apply them to Chinese-to-English translation of publicity on Chinese minority culture. Finally, we shall draw some rational conclusions based on specific cases.

\section{Literature Review}

Narrative is a notion applied in many disciplines, such as literature, sociology, and second language acquisition research. In different disciplines the notion may involve different contents, methods, and techniques.

\footnotetext{
Acknowledgements: This paper is funded by Guizhou Province’s 2014 Comprehensive Academic Disciplinary Reform for the English Major and Guizhou Province's 2015 Excellent Talent Cultivation Project "Colorful Guizhou Excellent English Communication Talent Cultivation".

XIAO Tang-jin, Ph.D. in Linguistics, Professor of English, Dean of School of Foreign Languages, Guizhou Minzu University, Guiyang, China.
} 
Yet, what is common are the personal experiences of participants and onlookers. Hence, narrative is an important path for disciplinary construction. The narrative theories started from literary critics in the 20th century, such as Vladimir Propp (who proposed "function”, a concept in anthropology, as a unit in analyzing folk stories, under which there are 31 functions in all types of stories), Roland Barthes (whose monograph Mythologies published in 1957 analyzes public culture), Tzvetan Todorov (who made great contributions to narrative structure, which, according to him, includes three levels, namely, philology, syntax, and morphology, syntax further divided into proposition and sequence), Gerard Genette (who assumed that there are three narrative points of view, namely, omniscient narrative-narrator $>$ characters, internal narrative-narrator $=$ characters, and external perspective — narrator < characters), and Algirdas Julien Greimas (who established a set of narrative grammars based on structural semantics). In these studies narrative is divided into two general levels, that is, story and discourse, involving three linguistic levels, that is, semantics, syntax, and vocabulary, and three grammatical categories, that is, time, genre, and mode, hence constituting a "233 model". Greimas borrowed two terms from linguistic structuralism by Saussure, i.e., signifier and signified. Signifier is a linguistic symbol, while signified refers to objects, persons, phenomena, facts, and emotions in material and mental world, including concrete and abstract aspects. In literary narrative there are several relationships between signifier and signified: one-to-one, one-to-many, and many-to-one.

Narrative theories have been widely applied in literary creation, literary research, and even second language education, where narrative space, narrative person, flat figure, and round figure are frequently mentioned. According to Li (2005, pp. 14-16), grow-up novels could embody a typical narrative story structure in temporal order: temptations, departure, tests, puzzlement, inspirations, loss of innocence, and understanding of life and self. Narrative rhetoric holds that besides "author" and "author's voice” there are "implied author" and "implied voice”. You and Yu (2019, pp. 111-119) advocate the concept of sensory and perceptive narrative, thinking that narrative is an outcome of perception's organization and integration of senses, or rather the conceptualization of external world inside internal world, an understanding of things and surrounding events. Literary characters differ from each other, playing different roles in texts. This proposition allows us to analyze the features of characters in action, probably a match between mental world and external behavior. Narrative concerns story, discourse, and narrative acts, which are combined in an organic way, going through the three stages of narrative beginning, topic lead-in and/or transfer, and plot ending. Fang (2019, pp. 1-13) studies the beginning model of Huaben novels (classic Chinese novels based on story-tellers' scripts, hence also known as story-tellers' novels). Generally, there should be an introducing part, characterized with such words as "the verses go on in this way", "the poems say like this", and "word proceeds as follows". In topic transfer there are such interactive evaluative words as "word turns to...”, "you may have never heard of this”, and "as you should be informed of this”. Zhao (2019, pp. 147-153) expounds space logic in repetitious narrative, according to which space repetition can be divided into convergence, complementation, and polyphony in logic forms. Logic space is an interesting explanation of narrative in structuring plots. Swain, Kinnea, and Steinman (2015) regard narrative perspectives as part of socio-cultural theories, and apply them to second language education research. As second language education is related to second language acquisition and translation teaching, narrative perspectives play a guiding role in these fields in a constructivist way. 
In the past two to three decades translation theories have witnessed breakthrough achievements, no more confined to form or functional equivalence and "faithfulness, expressiveness and elegance" in the conventional sense. Cultural turn, linguistic turn, and interdisciplinary turn have become hot points in translation research. Baker (2006, pp. 158-176) puts forward narrative translation approach, and applies it to translation theories and practice, acknowledged by House (2014). Mason (2014, pp. 36-54) examines translation theories and practice from the angle of sociology. According to him, translation is a socio-textual practice, in which the target text is a path for negotiating, reinforcing, or challenging power relationship. Snell-Hornby (2006) finds that since 1980s cultural turn has occurred in translation theories and practice, embodied in such propositions as the Skopos theory, the manipulation theory, the receptive aesthetics, law court translation, advertisement translation, simultaneous interpretation, gender-based translation, and corpus-based translation, and that these new approaches are further developments of Eugene Nida's functional equivalence.

Chinese minority culture is rich and charming, and the cultural turn in translation is conducive to the publicity of Chinese minority culture on the international stage. Narrative translation approach, a cultural turn in nature, has been rarely used in this regard. Hence, in the following part the writer shall introduce narrative translation perspectives, propose two narrative translation models, and apply them to the Chinese-to-English translation of publicity on Chinese minority culture. It is hoped that the operation procedures and mechanism could be identified in narrative translation approach to the publicity on Chinese minority culture.

\section{Narrative Perspectives of Translation}

Baker (2014) illustrates the theory of narrative translation. The narrative perspectives of translation are directly related to socio-narrative or sociological narrative approach, taking narrative as understanding the world and our positions and roles in the world, and thus it is a constructivist disciplinary way of seeing and perceiving. There are two fundamental assumptions as to the relationships between persons, environment, and stories spread. First, we often lack direct and non-mediated access to reality. Specifically speaking, our contact with reality is made through self-narration and other-narration of the living world. Second, the stories we narrate are not only the media we have access to, but also a construction of reality. In this sense, translation is assumed as a form of narration or re-narration, which constructs rather than represents the events and characters re-narrated in another language. In the approach of narrative translation, the translators (including written and oral translators) are not seen as brokers for cultural encounters beyond translating acts, but they participate in configuring these cultural encounters. The translators are embedded in narration, making explanations, revisions, changes, and communication through narratives. In this sense, their most important role is manipulation in the narrating or re-narrating process. Narrative perspectives grant them sufficient agency, acknowledging their complex role of decision-making in society.

According to narrative translation perspectives, the discourse analysis unit is a complete narrative structure, that is, a complete story, including characters, setting, outcome, and plot. Based on this, it should not exclude nor mainly concern the recurrent linguistic models in texts. In another word, narrative could be realized through various media, for example, written and oral texts, images or pictures, forms, colors, fashions, and dressing. A single narrative structure may have partial impact but may also affect the entire narrative structure. Besides, individual narrative structures are interrelated and can be hardly clearly differentiated. 
To realize narrative translation, we need two specific tools, that is, narrative typology and relevant narrative features. There are four types of narrative: personal narrative, public narrative, conceptual or disciplinary narrative, and meta narrative. Personal narrative is about our positions in the world and the stories of our experiences, which may be narrated either through self-narrating or other-narrating. Public narrative concerns the stories shared by a group or community. Conceptual or disciplinary narrative relates to academic or disciplinary narrative for research purposes. Meta narrative has much to do with the significance of events, showing highly abstract features, such as nationalism, enlightenment, capitalism vs. Communism, social progress and globalization. In translation practice personal narrative is interwoven with public narrative in a dialectical way. Due to different personal, institutional, or social purposes, sometimes public narrative is emphasized while at other times personal narrative is highlighted. For instance, the Jews suffered much persecution and even massacres during the Second World War, and their survivors told these miserable past events to the others. Through the translated texts, these personal stories narrate the atrocities and pains the Jews were dealt with. Readers could then understand how the translators made their choices about the contents and means of translation. Through personal narrative we could find how the translators showed the whole social framework as well as the identities, occupations, and purpose of social members. The narrative translation approach could display two sets of features: (1) selective appropriation of contents, temporality, relationality, and causal emplotment; (2) particularity, genericness, normativeness, and narrative accrual. As we cannot put every and each detail of experiences into narrative, the selection of contents is necessary, which could serve the foregrounding or backgrounding of plots. Narrative is embedded into a certain time and space, accordingly possessing temporal-spatial features. The characters, events, linguistic items, design and arrangement, and imagery should be related to the whole narrative. The whole narrative structure could involve many stories, which should interact with each other in a causal way. Narrative speciality is the special aspect of stories, and narrative genericness are story types, for instance, complaints and detective stories, which are different genres. Narrative should have some norms, and changes must occur within acceptable scope. Narrative accrual means the aggregate effects of stories, which could delineate the entire narrative structure. In this way, in the process of narrative translation the translators play an important role, with the contents, forms, norms, and details of target texts within their command. They change their former identity of "replicators" of source texts into implicit authors of target texts.

\section{Two Narrative Translation Models in Chinese-to-English Translation of Publicity on Chinese Minority Culture}

The key factors for narrative translation perspectives include characters, settings and plot, and even moral or comments. In the process of Chinese-to-English translation of publicity on Chinese minority culture, attention should be paid to discrepancies between source text culture and target text culture, which are more often than not shown through the foreignness of story settings, characters, and events. Nord (1997, pp. 93-101) studies the English-to-German, English-to-French, and English-to-Italian translation of Alice in Wonderland, covering the localization of characters and the reconstruction of nursery rhymes in the novel so as to let the target readers better accept the translated versions and furthermore increase their readability and the readers' interest and participation in discussions. Watson (2007, p. 50) translates an excerpt from The Analects of Confucius into English as follows: 
Example 1: (《论语》述而篇第七: 第17节) 子所雅言, 《诗》、《书》、执礼, 皆雅言也。

Watson's translation: The Master used the correct pronunciations when speaking of the Odes and Documents or the conduct of rituals. On all such occasions, he used the correct pronunciations. (As opposed to the pronunciations of Confucius' native state of Lu)

In Example 1 through narrative Watson describes the official or correct pronunciations in preaching classics, namely, Shaanxi pronunciations, which were assumed by Confucius as appropriate in publicizing Zhou rituals. The translator renders much care about the official pronunciations, bracketed as an annotation. This is a way of reducing cultural distance, and combined with the preface for an introduction to the ideas in The Analects of Confucius, the western readers could better accept Confucian teaching. Besides, the terms of Odes and Documents could evoke a literary taste in the minds of western readers, and the use of italics reminds them of Chinese literary classics. We could regard the English version by Watson of The Analects of Confucius as a good example of narrative translation.

Watson's narrative translation could be imitated in the Chinese-to-English translation of publicity on Chinese minority culture. Consider the following example:

Example 2: 《阿蓉》是苗族叙事歌, 流传于黔桂交界的都柳江、月亮山、大苗山和雷公山下的榕江、从江、 雷山、丹寨、三都、荔波等县的苗族地区。传说在古代, 古州杨家湾辣子寨有一个大苗寨, 寨中羲公和欧奶生有 一女, 名叫耶蓉, 尊称阿蓉。阿蓉生得洁白漂亮, 亭亭玉立, 既聪明伶俐, 又心灵手巧, 更有一副好歌喉, 远近 闻名。长大后, 远近求亲者踏破门槛, 她都不如意。阿蓉爱上摆内寨的后生阿珙, 阿珙长得英俊、彪悍, 是个出 了名的歌师和芦笙手。最后, 阿蓉不为钱财所心动, 也未遵姑表亲的风俗, 只与阿珙定下终身, 并与官府展开了 斗争, 最后在众亲友的帮助之下, 终于与阿蓉结为夫妻。作品意义深刻, 很有鼓舞作用, 现在当地的苗族群众仍 以会唱《阿蓉》为荣, 而其故事内容也成为鼓藏祭礼内容之一, 足以见阿蓉在苗族心中的地位。 (Encyclopedia of Traditional Minority Culture of Guizhou Province, 2013, p. 133)

Tentative English translation through narrative translation: “A Rong” is a narrative of the Miao people (known as Hmong in international academic community) in China, popular in the Miao areas of Liujiang River, Moon Mountain and Big Miao Mountain on the border of Guizhou and Guangxi and the Miao areas of Rongjiang, Congjiang, Leishan, Danzhai, Sandu and Libo Counties at the foot of Leigong Mountain. According to the legend, in ancient times there was a big Miao village in Yangzhouwan of Guzhou, where Xigong (husband) and Ounai (wife) had a daughter named Yerong, respectfully called A Rong. The daughter was fair, beautiful and slender as well as bright and smart, with a sweet voice known near and far. When she grew up, many young men came to her home for courtship, but she was not interested in them. In fact, she felt attached to a lad named A Gong in Bainei Village, a famous singer and Lusheng player, who was handsome and strong. She did not give in to the temptations of money or obey the tradition of marrying her cousin, but made a vow of marriage with A Gong, and they fought together against the corrupted government. Eventually, with the help of their relatives and friends the two lovers got married. This story occupies an important place in many people's hearts, for the Miao people take pride in being able to recite the instructive story of A Rong. The narrative has significant value in literature, and is part of Miao’s Guzang Festival (a sacrifice celebration held every 12 years) celebrations.

In Example 2 the author of this paper purposefully puts annotations to two Miao culturally-loaded terms, Miao people and Miao’s Guzang Festival, into brackets so as to make western readers better know Chinese minority culture. Similarly, Xigong and Ounai, two Miao names, seem foreign to western readers, and so annotations in brackets are adopted to make them know they are the names of husband and wife respectively. In this way, their reading interest may be increased. It is clear that the translator acts out his translator's subjectivity. Example 2 is mainly public narrative, which typifies the meta narrative of loyal love and unyielding spirit. The 
translated version replicates the two types of narrative of source text. It could be called "the annotated narrative translation model” as shown in Figure 1.

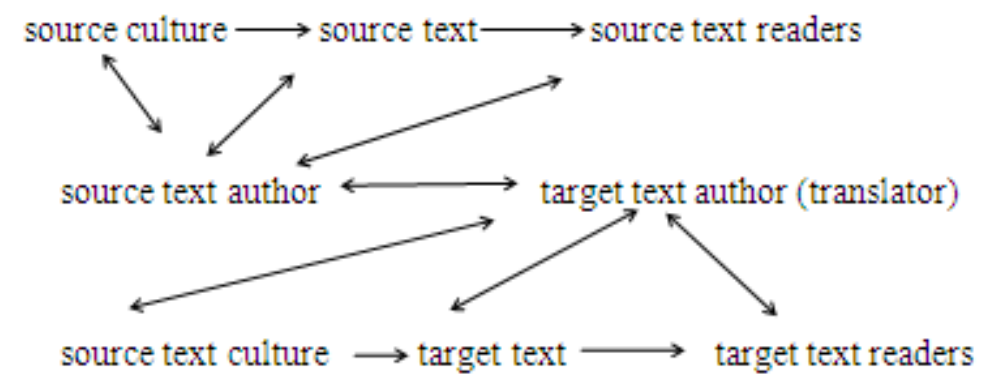

Figure 1. The annotated narrative translation model.

Figure 1 indicates: (1) There is an interactive relationship between the target text author (translator) and the source text author, and the translator's relationship with source text culture, source text, and source text readers is realized through the source text author; (2) there is an interactive relationship between the target text author (translator) and target text culture, target text, and target text readers, which is realized through the target text author (translator); (3) source text culture gives birth to source text, aiming at source text readers, and similarly target text culture leads to target text, designed for target text readers. Generally the two relationships are uni-directional. In the translating process, the target text author (translator) is the center, who makes some limited revisions to source text, basically abiding by Eugene Nida’s functional equivalence or dynamic equivalence.

Since the mid-1980s the culture turn has occurred in western translation circles. Snell-Horby (2006) mentions the Manipulation School, which stresses its new norms for literary translation studies, such as Gideon Toury's descriptive translation studies, José Lambert and Hendrik van Gorp's descriptive translation model studies, Susan Bassnett's drama translation studies, and André Lefevere’s re-writing as translation studies. The Manipulative School's focus is target text culture rather than source text culture. In this model the translator's subjectivity is highlighted, who cares much about target text receptors and target text culture, and may thus make much revision in contents and translation methods or techniques. Hence, the traces of re-writing are obvious. This model may be called "the manipulative narrative translation model” as shown below in Figure 2.

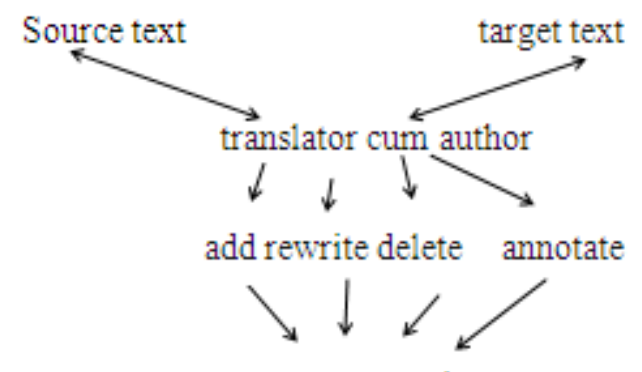

meta narration

Figure 2. The manipulative narrative translation model.

Figure 2 indicates: (1) In the Chinese-to-English translation of publicity on Chinese minority culture the translator must take care of both source and target texts, and thus has two identities, the translator of source text 
and the author of target text, and the relationship is bi-directional, that is, both texts have much to do with the translator in terms of content, message and linguistic form; (2) the translator establishes a dialogue with source text, the source text author and target text readers, and clearly manipulates the process, and in the process source text readers may be relegated to the secondary position; (3) the translation techniques serve the purpose of emphasizing meta narrative, or rather the text theme or spirit embodied by the translator. Compared with "the annotated narrative translation model”, “the manipulative narrative translation model” gives priority to meta narrative, and the so-called public narrative and personal narrative move around meta narrative. For instance:

Example 3: 姊妹节是苗族娱乐性节日。流行于黔东南苗族侗族自治州台江、施秉、黄平等县。黄平县、施秉 县过节的时间是每年农历二月十五, 而台江县则是三月十五。苗语叫 “浓嘎良”。节日以青年女子为中心, 以邀 约情人一起游方对歌、吃姊妹饭、跳芦笙木鼓舞、互赠信物、订立婚约等为主要活动内容。最具代表性和影响力 的是施洞地区的姊妹节，时间是每年农历三月十三日至十六日。十三日，各村寨的姊妹们都上山去采撷木叶、姊 妹花等花草树叶, 制作黑、红、黄、蓝、白五色糯米饭。十四日下田捕鱼捞虾, 凑钱购买鸭、肉、蛋等, 于某家 摆设 “姊妹餐” 宴请外房族的小伙子。十五、十六日是节日的高潮。白天, 姊妹们梳妆打扮, 穿上漂亮的衣裙, 佩戴华丽的银饰与小伙子在笙鼓场上跳芦笙木鼓舞; 晚上, 男男女女相聚于游方场上对唱情歌, 谈情说爱。节日 结束后, 姊妹们用竹篮盛装五色糯米饭, 饭里藏匿松针、椿芽、辣椒等爱情标识, 把自己的心思传达给男子。苗 族姊妹节已列入第一批国家级非物质文化遗产名录。(Encyclopedia of Traditional Minority Culture of Guizhou Province, 2013, p. 132)

Tentative English translation through narrative translation: Sisters’ Festival is an entertainment festival for the Miao people, called Nong Ga Liang in the Miao language, popular in Taijiang, Shibing and Huangping Counties of Qiandongnan Miao and Dong Autonomous Prefecture of Guizhou Province. In Huangping and Shibing Counties the festival is held on lunar February 15 while in Taijiang County on lunar March 15. The Chinese Xinhua News Agency reported on April 19 (lunar March 15), 2019 that thousands of Miao people sing antiphonal songs as a way of celebration in Taijiang County, Guizhou Province. The size of participation is spectacular indeed. Young women are the center of the festival, and the activities include inviting lovers for singing duet (You Fang), eating Sisters' Rice, dancing to the accompaniment of Lusheng and wooden drum, exchanging gifts as love tokens, and making engagements of marriage. The most influential Sisters' Festival is observed in Shidong area from lunar March 13 to 16. On this occasion the young women of each village would collect leaves and Sisters' Flowers, and make sticky rice in 5 colors_black, red, yellow, blue and white. On the 14th people would go to the fields for fish and shrimps, raise money for duck, pork and eggs, and set a "Sisters' Meal" for young men of other clans. The 15th and 16th are the peak times. In the daytime the Sisters would dress up at their best, wear splendid silver ornaments and dance with young men at the Lusheng and drum site to the accompaniment of Lusheng and wooden drum; at night men and women would gather at the You Fang site for singing duet and dating. After the festival is over, the Sisters would hold the colorful sticky rice in bamboo baskets, with pine needles, Chinese toon sprouts and chili inside as tokens of love, and send it to their attached men. According to Chinese ethnologists and other international scholars, this festival embodies strong flavors of inherited customs and striking ethnic notions of love and marriage, hence regarded as “Oriental Valentine's Day”. Miao, an important component of the Chinese people, have exerted much impact on the domestic and international stages due to their distribution in and outside China, and naturally Sisters' Festival has been listed as one of the first national intangible cultural heritages. The following two pictures show a clear sign of how the festival looks like, judging from the girls' dressing and the women's active participation in making colorful sticky rice. Also, they reveal the dominating role of Miao women in social life, thus a window of vestiges of matriarchal society passed down from generation to generation. 


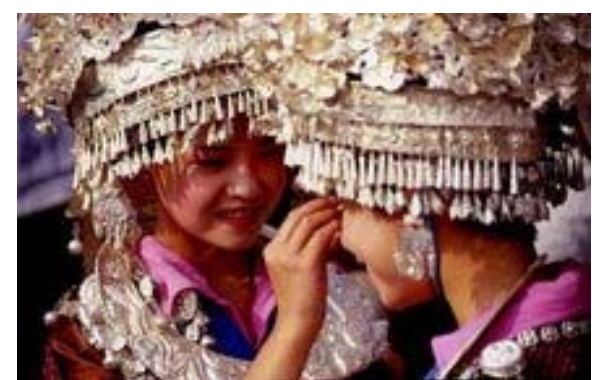

Figure 3. Miao girls in splendid costumes on Sisters’ Festival.

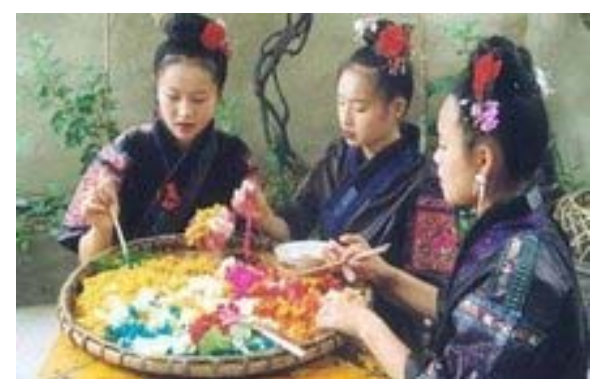

Figure 4. Miao women making colorful sticky rice on Sisters’ Festival (Source: https://baike.so.com/doc/5706844-5919563.html).

In Example 3 the translation includes public narrative, personal narrative, and meta narrative. Public narrative mainly describes the holiday whereas personal narrative involves the translator's opinion or comment on the celebrations. Meta narrative in this regard reveals the folklore experts' views. The two pictures can be seen as a combination of public narrative and personal narrative. On the one hand the pictures show the cameraman's reportage and perspective; on the other hand, the cameraman is a spectator, standing for the perspective of the people present as well other readers absent-a multimodal feature. Table 1 shows the arrangement of personal narrative, public narrative, and meta narrative in Example 3: 
Table 1

Narrative Translation of Miao's Sisters' Day

Personal narrative:

1. The Chinese Xinhua News Agency reported on April 19 (lunar March 15), 2019 that thousands of Miao people sing antiphonal songs as a way of celebration in Taijiang County, Guizhou Province. The size of participation is spectacular indeed.

2. Miao, an important component of the Chinese people, have exerted much impact on the domestic and international stages due to their distribution in and outside China...The following two pictures show a clear sign of how the festival looks like, judging from the girls' dressing and the women's active participation in making colorful sticky rice. Also, they reveal the dominating role of Miao women in social life, thus a window of vestiges of matriarchal society passed down from generation to generation.

Significance:

1. Translator's voice

2. Dialogue between the translator and target text readers

3. Translator's subjectivity

Public narrative:

1. Sisters' Festival is an entertainment festival for the Miao people, called Nong Ga Liang in the Miao language, popular in Taijiang, Shibing and Huangping Counties of Qiandongnan Miao and Dong Autonomous Prefecture of Guizhou Province. In Huangping and Shibing Counties the festival is held on lunar February 15 while in Taijiang County on lunar March 15.

2. Young women are the center of the festival, and the activities include inviting lovers for singing duet (You Fang), eating Sisters' Rice, dancing to the accompaniment of Lusheng and wooden drum, exchanging gifts as love tokens, and making engagements of marriage. The most influential Sisters' Festival is observed in Shidong area from lunar March 13 to 16. On this occasion the young women of each village would collect leaves and Sisters' Flowers, and make sticky rice in 5 colors_black, red, yellow, blue and white. On the 14th people would go to the fields for fish and shrimps, raise money for duck, pork and eggs, and set a "Sisters' Meal" for young men of other clans. The 15th and 16th are the peak times. In the daytime the Sisters would dress up at their best, wear splendid silver ornaments and dance with young men at the Lusheng and drum site to the accompaniment of Lusheng and wooden drum; at night men and women would gather at the You Fang site for singing duet and dating. After the festival is over, the Sisters would hold the colorful sticky rice in bamboo baskets, with pine needles, Chinese toon sprouts and chili inside as tokens of love, and send it to their attached men.

Significance:

1. Statement of the event process

2. Presentation of objective aspects

3. Main content of target text

Meta narrative:

According to Chinese ethnologists and other international scholars, this festival embodies strong flavors of inherited customs and striking ethnic notions of love and marriage, hence regarded as “Oriental Valentine's Day”. Miao, an important component of the Chinese people, have exerted much impact on the domestic and international stages due to their distribution in and outside China, and naturally Sisters' Festival has been listed as one of the first national intangible cultural heritages.

Significance:

1. Professional interpretation of the minority festival by experts

2. Indication of the folklore importance

3. Communication and interaction with target text readers

The translated version adds some information so as to highlight the personal narrative of the translator. In Example 3 the Chinese Xinhua News Agency, an official news institution, published a report about Sisters' Festival, which is added as a reliable source of information, a clear sign of the translator's manipulation. Miao's Sisters' Festival is an important occasion of minority celebrations, and the translator does not need to be confined by the content and form of source text, hence able to operate manipulation with efforts so as to show the charms of the holiday.

\section{Conclusion}

Narrative may occur not just in stories, but also in descriptions, expositions, and arguments with story-telling elements. Put in another way, story-telling occurs in various ways. Narrative translation models are particularly suitable for the translation of minority people's festivals, customs, and tales. As is known, translators are the bridge between source text culture and target text culture, and they must show their subjectivity in a 
positive sense. The Chinese government stresses the shared future for human beings, applauded inside and outside China, and thus translators must reflect the reality in publicizing Chinese minority culture. Also, the translators' voices (seen as personal narrative) must be related to the topic, better based on official reports or famous experts' research, which constitute intertextuality with the translators' subjectivity. Furthermore, the translators' voices should not exceed the main content of target text, that is, less than 50\%. In Examples 2 and 3 we have followed such principles.

Narrative translation models (the annotated narrative and the manipulative translation models) could enrich cultural turn studies of translation. They are also contributions to cross-cultural communication translatology. Through these two models the translators' roles are better displayed and the publicity of Chinese minority culture witnesses an open window for exchange with the global audience.

\section{References}

Baker, M. (2006). Translation and conflict: A narrative account. London and New York: Routledge.

Baker, M. (2014). Translation as re-narration. In J. House (Ed.), Translation: A multidisciplinary approach. New York: Palgrave Macmillan.

Fang, M. (2019). The tradition of Chinese storyteller script and its inheritance in contemporary Chinese narration and grammar. Modern Rhetoric, (1), 1-13.

Guizhou Ethnic Affairs Commission. (2013). Encyclopedia of traditional minority culture of Guizhou Province. Guiyang: Guizhou Education Press.

Li, S. Z. (2005). Analysis of the narrative structure and major character prototypes of American grow-up novels. Journal of Inner Mongolia University for Nationalities, (1), 14-16.

Mason, I. (2014). Discourse and translation-a social perspective. In J. House (Ed.), Translation: A multidisciplinary approach. New York: Palgrave Macmillan.

Nord, C. (1997). Translating as a purposeful activity: Functionalist approaches explained. Manchester/Kinderhook: St. Jerome Publishing.

Snell-Hornby, M. (2006). The turns of translation studies. Amsterdam/Philadelphia: John Benjamins.

Swain, M., Kinnear, P., \& Steinman, L. (2015). Sociocultural theory in second language education: An introduction through narratives. Clevedon, UK: Multilingual Matters.

Watson, B. (2007). The analects of Confucius. New York: Columbia University Press.

Xiao, T. J. (2018). Cross-cultural communication translatology: Theories and practice. Journal of Literature and Art Studies, (12), 1687-1695.

You, L., \& Yu, D. Z. (2019). Perceptual narration of modern fiction. Journal of Fujian Normal University, (1), 111-119.

Zhao, C. B. (2019). Space logic in repetitious narration. Inner Mongolia Social Sciences, (1), 147-153. 